\title{
Perception of Millennials Towards the Implementation of Automation Staying in Ciputra World Hotel Surabaya
}

\author{
Lexi Pranata Budidharmanto ${ }^{1}$, Ikhsan Budi Riharjo ${ }^{2}$, Jessica Grace Susanto ${ }^{3 *}$ \\ ${ }^{1}$ Sekolah Tinggi Ilmu Ekonomi Indonesia (STIESIA) Surabaya, Indonesia \\ ${ }^{2}$ Sekolah Tinggi Ilmu Ekonomi Indonesia (STIESIA) Surabaya, Indonesia \\ ${ }^{3}$ Tourism Department, Faculty of Tourism, Universitas Ciputra Surabaya, Indonesia \\ *Corresponding author email: llimbing@ @iputra.ac.id
}

\begin{abstract}
The implementation of automation is very much needed for millennials generation because in the middle of year 200, the hotel industry, especially in the city of Surabaya has entered the era of the industrial revolution 4.0, which is shown by the developing digital technology rapidly. This affects a person lifestyle from the way they work, socializing, behavior or habit, making decision to shop and stay somewhere. In determining where to stay, the millennials taking advantage of technological advances by looking for preferences on website or social media. Using the post-positivism philosophy and descriptive approach to the Hotel Ciputra World Surabaya as the object of research, four informants were chosen to represent millennial generation as hotel guests and triangulation of resources was conducted with hotel staff managing technology and dealing with guests at the hotel. It turns out that the automation technology that has been implemented at Ciputra World Hotel Surabaya does not currently have a significant impact on the decision of millennial generation stays due to the lack of information about the existence and benefits of technology to guests. This failure became a lesson for Ciputra World Surabaya Hotel to first explore the perceptions expected by millennials as the future market segment regarding the implementation of automation first, namely the concept of all in one in mobile apps.
\end{abstract}

Keywords: Implementation of Automation, Millennials.

\section{INTRODUCTION}

Implementation of Automation is very much needed in the hotel industry, especially the city of Surabaya, which has entered the era of the millennial generation or the era of the industrial revolution 4.0, which is marked by the rapidly developing digital technology[1][2].

This affects the side effects that are not limited, to the effect on a person's lifestyle from how to work, how to socialize, patterns of behavior or habits, make decisions when shopping and staying somewhere. The existence of the industrial revolution 4.0 has led to many advancements in automation implemented in hotels, and has the goal of being able to meet the needs of consumers personally, increase flexibility when accessing hotels, optimizing consumers when making decisions, efficiency and increasing consumer productivity and the workforce in it. The mindset of millennials before deciding where to stay, i.e. utilizing technological advances, by looking for preferences on websites or social media[3][4][5].

However, if it is related to the purpose of automation, the impact on the decision to stay at the hotel apparently has not yet had a significant impact 
because there are some hotel guests who have difficulty or cannot use and access the technology provided easily and simply[6][7].

Explain millennial generation perceptions of the implementation of automation that has an impact on the decision to stay at Ciputra World Hotel Surabaya. For researchers, research is useful in increasing the knowledge of writers relating to the development of automation for the millennial generation[8]. For study programs, it is expected to be knowledge and learning from the development of automation in the hospitality industry. For agencies where internships can be used as input in determining policies and evaluations to improve the quality of hotel services.

\section{RESEARCH METHOD}

This research was carried out systematically using a type of research or a qualitative approach. In this case, the researcher uses the theoretical foundation derived from the mastery of research journals and theory books as a reference for understanding and exploring profound information both in writing and orally (direct interviews with informants and direct observation in the field) [9][10][11].

In this case, the researcher plays a major role in the entire research process, starting from selecting topics, approaching topics, collecting data, interpreting, and drawing conclusions about how the environment around them can influence their behavior. In this study, researchers looked at and observed the guest speaker, Ciputra World Surabaya Hotel, undergoing an internship process for six months.

This research was conducted at Ciputra World Hotel Surabaya; located in a strategic location, close to office areas, shopping centers, food, and entertainment venues; which is located at Jalan Mayjen Sungkono no. 87-89, Gunung Sari, Hamlet Pakis, West Surabaya which is an exclusive five-star hotel that has implemented automation technology in several electronic services in it.

In research, there are 4 sources will be used to collect data, namely:

\section{a. Observation}

Observation is a way to collect data based on direct observation of the physical symptoms of research objects. The type of observation used is non-participant observation where the writer sees or listens to certain social situations without actively participating in them. This system was carried out by the author during the internship process at Ciputra World Hotel Surabaya

b. Interview

Interviews conducted by researchers are in-depth interviews in a structured and free with informal conversation, which uses a question pattern that can be changed when asking questions and can be adjusted to the needs and conditions of the informant.

c. Literature Study

This literature study is used to obtain theoretical data and a deep understanding of millennial generation perceptions of the Implementation of Automation in determining the decision to stay at the Ciputra World Hotel in Surabaya.

d. Documentation

Documentation is the process of taking pictures and sounds using an intermediary tool, aimed at making data retrieval easier. An intermediary tool used for documentation is a camera or voice recorder to support research. In this study, it will be obtained directly from the field in the form of interview photos, location photos, recordings, and other information about Ciputra World Hotel Surabaya.

Data obtained from interviews, observations, and documentation will then be analyzed using triangulation techniques. This technique is an analytical method to check the truth of information from a variety of different informants. Triangulation techniques include 4 methods, namely[9][10][11]:

a. Source Triangulation

Source triangulation is exploring the truth of information through various data sources to obtain data, by knowing the reasons that occur from differences in existing phenomena.

b. Triangulation Method

Method triangulation is to compare data in different ways with free interviews and unstructured interviews, observations and surveys. To check the truth, the writer can use different informants.

c. Triangulation of Researchers

Triangulation of researchers is to analyze data based on observations and interviews, using more than one phenomenon that understands and has experience.

d. Theoretical Triangulation

Theoretical triangulation utilizes two or more theories to compare.

In this case, the researchers used the researcher triangulation technique, which compared informants to more than one person to obtain data.

\section{RESULTS AND DISCUSSION}

Overview of Research Objects

1. Company Profile

Ciputra World Surabaya Hotel is a 5-star boutique hotel that operates under Swiss- Belhotel International (SBI) management. Swiss-Belhotel International was founded in 1987 by Peter Gautschi (originally from 
Switzerland), James K.Tam (Hong Kong) and Gavin M.Faull. Until now, SBI is led by Gavin M. Faull and vice chairman James K.Tam. Ciputra World Surabaya Hotel is one of the properties built under the management of PT Ciputra Sukses Mitra Hotel, which was inaugurated on November 27, 2014. The location of this hotel is located in a strategic area because it is adjacent to Ciputra World Surabaya Mall, on Mayjen Sungkono Street no. 87-89, Surabaya. From the beginning of its operation to the present, the hotel is under the leadership of General Manager Christiane Wasfy who is from Austria. The concept of Ciputra World Surabaya Hotel is classic and elegant, it can be seen in terms of the interior of the hotel building, which was inspired by contemporary artists from Colombo. The hallmark of the hotel is almost on every floor can be found statues or dancers, known as Botero.

\section{Company Vision and Mission}

In managing hotels under the auspices of Swiss-Bell International, Hotel Ciputra World Surabaya has a 5 star standard in maintaining the quality of the employees who work at the hotel. Hotel Ciputra World Surabaya has a vision "To be a leader in the international hotel class with a unique blend of Swiss hospitality and professionalism and from the passion and service of Asians." While the company's mission is "To be a leading hotel management group with a worldwide reputation for commitment to management, and service experience where passion and professionalism are the hallmark of the SBI group's brand.

3. Enterprise Automation Technology Hotel Ciputra World Surabaya has a variety of automation technologies that can be felt by hotel guests, both from hotel room facilities and can be accessed to outside the hotel such as mobile apps in getting the latest information about hotels, where this technology is the object of research in gaining millennial generation perceptions of automation technology.

Description of Research Informant

In this study, the authors conducted an interview process with 6 informants who were divided into 4 categories according to their interests and work performed. that is:

1. Influencers / bloggers from Surabaya as the representative of millennial generation votes

2. Assistant Director of Sales Marketing or ECommerce Sales Supervisor as hotel staff who understands hotel marketing strategies in inviting guests to stay

3. Hotel guests

4. Student interns at Ciputra World Surabaya hotel for 6 months and complete hotel orientation learning

List of 6 informants are:

1. Willy Antony, 23 years old, Public Speaker, Hotel Guest

2. Rani Dian, 22 years old, Student, Hotel Guest

3. Amanda Kohar, 30th, Influencer, Hotel Guest

4. Ricky Christanto, 20 years old, Student, Internship Student

5. Dary Rafly, 35, Assistant Director of Sales Marketing, Hotel Staff

6. Okky Handoko, 40th, E-Channel Manager, Hotel Staff

During the research, the author has found a lot of information about Implement Automation and how Implement Automation plays a very significant role in the generation of milenal in decision-making where to stay. Table 1. Triangulation of Conventional Services.

A. Interview

- Not all staff are able to explain and respond well, there are even some staff who do not show hospitality

- The front office department does not respond quickly to guests when guests check-in and carry out personal activities that should not be seen

- There has been a delay in ordering food service delivery from 4-6pm and there was no explanation from staff

- Not all staff are able to show initiative

- All staff look neat according to hotel standards

B. Observation

- Almost all head of departments are able to explain information about the hotel very well

- Not all departments are able to respond to problems quickly and well

- Often there are delays in food delivery

- Not all staff can provide tolerance and attention evenly to the student interns

- Only a few staff including interns are neatly dressed and meet hotel standards

C. Literature Review Parasurman in Tjiptono et al [12][13][14].

- Has the ability to foster a sense of trust by 
showing hospitality

- The staff is able to assist guests in responding to problems properly and quickly

- Staff are able to provide services as promised accurately

- Staff are able to show personal attention and interaction to guests and the company

- Visible physical evidence of the facilities, products, and whereabouts of hotel employees Table 2. Triangulation of Electron Services

\section{CONCLUSION}

After conducting the research, the conclusion of this study is the perception of the millennial generation of the implementation of automation that has an impact on the decision to stay at Ciputra World Hotel Surabaya, which does not significantly affect the increase in stay decisions, because there are still many hotel guests who are unaware of the existence of automation technology. Automation technology expected by millennial generation is the development of mobile apps with the all in one concept.

\section{REFERENCES}

[1] Prasetyo, H., \& Sutopo, W. 2017. Perkembangan Keilmuan Teknik Industri Menuju Era Industri 4.0. Surakarta: Seminar dan Konferensi Nasional IDEC 2017

[2] Rahman, F. 2018. Karakteristik Model Dan Analisa Peluang Tantangan Industri 4.0. Banjarmasin: Teknik Informatika Politeknik Hasnur.

[3] Nabila, P. 2018. Peranan Guest Relation Officer Dalam Mendapatkan Positive Review Melalui Online Review Di Hotel The Ritz Calton Jakarta Mega Kuningan. Surabaya: Universitas Surabaya.
[4] Sunjoto, N. 2018. Pengaruh Customer Online Review Dan Rating Terhadap Keputusan Pembelian Konsumen Di The Trans Resort Bali. Surabaya: Universitas Ciputra Surabaya.

[5] Bolton, R, N., Hoefnagels, A., Kabadayi, S., Loureiro, Y, K., Migchels, N., Thorsten, G., Parasuraman, A., \& Solnet D. 2013. Understanding Generation $\mathrm{Y}$ and their use of social media: a review and research agenda. Netherlands: Radboud University

[6] Ooi, B K., Lee, H, V., Lin, B., \& Wei, H, G. 2016. Mobile Aplication in tourism: The Future Of The Tourism Industry. Korea: Seoul National University of Science and Technology

[7] Morosan, C. 2016. Modeling Guests Intentions To Use Mobile Apps In Hotels: The Roles Of Personalization, Privacy, and Involvment.Vol.8 Iss 9.

[8] Bowen, J., \& Walen E. 2017. Trends That Are Changing Travel and Tourism. Texas: University Of Houston.

[9] Gunawan I. 2016. Metode Penelitian Kualitatif: Teori dan Praktik. Jakarta: Bumi Aksara.

[10] Mulyana, D. 2010. Metode Penelitian Kualitatif. Bandung: PT Remaja Rosdakarya.

[11] Subadi, T. 2006. Penelitian Kualitatif. Surakarta: Muhammadiyah University.

[12] Juliati \& Dwi R. 2008. Pengaruh Kualitas Pelayanan Terhadap Kepuasan Konsumen Hotel Palm Bondowoso. Jember: Universitas Jember.

[13] Malhotra, A., Parasuraman., Zeithaml, V, A. 2005. E-S-Qual: A Multiple-Item Scale for Assessing Electronic Service Quality. Florida: University of Miami.

[14] Olivia, N., \& Deborah C. 2017. Analisa Pengaruh Kualitas Produk Dan Kualitas Layanan Terhadap Kepuasan Pelanggan Dan Loyalitas. Surabaya: Universitas Petra Surabaya 